\title{
Water Resources Sustainability of Ulaanbaatar City, Mongolia
}

\author{
Naranchimeg Batsaikhan ${ }^{1,2}$, Jae Min Lee ${ }^{3}$ (D) , Buyankhishig Nemer ${ }^{2}$ and Nam C. Woo ${ }^{1, * \text { (D) }}$ \\ 1 Department of Earth System Sciences, Yonsei University, Seoul 03722, Korea; naranchimegb@gmail.com \\ 2 School of Geology and Mining Engineering, Mongolian University of Science and Technology, \\ Ulaanbaatar 216046, Mongolia; bbn@must.edu.mn \\ 3 Institute of Natural Sciences, Yonsei University, Seoul 03722, Korea; leejm03@gmail.com \\ * Correspondence: ncwoo@yonsei.ac.kr; Tel.: +82-2-2123-2674
}

Received: 17 May 2018; Accepted: 5 June 2018; Published: 8 June 2018

\begin{abstract}
Ulaanbaatar (UB), the capital of Mongolia, is one of the fastest-growing cities in the developing world. Due to increasing demand driven by rapid population and industrial growth, sustainable water resource management is required. Therefore, we investigated sustainability in UB from the perspective of water quality. During five sampling campaigns, we collected 135 water samples ( 58 from bedrock wells, 44 from shallow wells tapped into the alluvial aquifer, 24 from rivers, and 9 from springs). The hydrochemistry of the water samples was controlled by two major processes: $\mathrm{NO}_{3}$ contamination, and silicate and carbonate mineral weathering. The groundwater samples could be classified into three groups based on their $\mathrm{NO}_{3}$ levels and spatial distribution. Group 1 had natural background $\mathrm{NO}_{3}$ levels (median: $1.7 \mathrm{mg} / \mathrm{L}$ ) and silicate weathering-dominant water-rock interactions and was distributed in the alluvial aquifer along the floodplain. Group 2 was dominated by carbonate weathering processes, had a maximum $\mathrm{NO}_{3}$ concentration of $47.4 \mathrm{mg} / \mathrm{L}$, and was distributed between the riverbank and upslope area; overall, it reflected ongoing contamination. Group 3 was distributed in the upslope Ger districts and showed significant $\mathrm{NO}_{3}$ contamination (range: $64.0-305.4 \mathrm{mg} / \mathrm{L}$ ) due to dense and poor living conditions. The stable isotope signatures indicated that the city's major water supply from riverbank filtration (i.e., Group 1 wells) mixed dynamically with the river; therefore, it showed no sign of $\mathrm{NO}_{3}$ contamination. However, the isotope values and bedrock groundwater quality of wells in Groups 2 and 3 implied that they were closely connected, with the same water source, and showed a strong potential for expanding $\mathrm{NO}_{3}$ contamination toward Group 1 wells. To support sustainable development in UB, the implementation of appropriate institutional measures to protect and preserve water resources, with systematic spatio-temporal monitoring and a focus on Ger districts, is crucial.
\end{abstract}

Keywords: monitoring; nitrate; sustainability; Ulaanbaatar; water resources

\section{Introduction}

Mongolia, a landlocked country in central Asia, has a total area of about 1.5 million $\mathrm{km}^{2}$ and an average altitude of $1580 \mathrm{~m}$. Its climate is semi-arid to arid, with the mean annual precipitation ranging from $400 \mathrm{~mm}$ in the north to less than $50 \mathrm{~mm}$ in the southern Gobi region [1]. Due to global warming, the temperature in Mongolia has increased at least $2.14{ }^{\circ} \mathrm{C}$ since 1940 and is projected to increase by up to $5^{\circ} \mathrm{C}$ by the end of the 21st century [2].

As the political, industrial, and economic center of Mongolia, Ulaanbaatar (UB) is one of the fastest-growing cities in the developing world [3]. Rapid industrial development, including that in textiles, tanning, food processing, energy production, communications, and construction, is concentrated primarily in UB and has attracted people from rural areas, resulting in significant 
growth in the city's population from about 0.5 million in 1989 to 1.2 million in 2016 [4,5]. The rapid introduction of rural people into the city and the residential areas along the hillslope surrounding it (Ger districts) has caused many issues, including those related to water supply and waste treatment infrastructure.

Urban development in UB during the last several decades has caused a dramatic increase in water demand for drinking, domestic, and industrial use. As the city is located along the Tuul River, the central urban area receives water predominantly from wells tapped into the alluvial aquifer, a system that relies on bank filtration [6]. However, the expansion of the city has outpaced that of its infrastructure. Pipeline water distribution is limited to the urban center, and most residents in the outskirts purchase water for drinking and daily domestic use from kiosks. Most kiosks are associated with wells tapped into the bedrock aquifer, through which groundwater eventually discharges and feeds the river [7]. Consequently, the water level in the source zone, the alluvial aquifer, declined from $1.6 \mathrm{~m}$ in 1948 to $3.1 \mathrm{~m}$ in 1998 [8]. Seasonal water shortages have become increasingly common, and researchers have warned that the city will face critical water shortages in the near future $[9,10]$.

Industrial activities have become the principal sources of air, water, and soil contamination in and around UB. The quality of its water sources meets the standards for drinking and industrial uses, with concentrations of total dissolved solids (TDS) ranging from 60 to $100 \mathrm{mg} / \mathrm{L}$, remaining unaffected by sources of pollution in the city [10]. However, since the late 1990s, water quality in the downstream area of the Tuul River has deteriorated, due mainly to urban and industrial pollution [11-15]. Moreover, the unplanned expansion of Ger districts around the city has created a high potential for water contamination due to a lack of appropriate sanitation and sewage systems, which are based on pit latrines. By consequence, the area around UB has changed dramatically with the rapid growth of the city, which could have severe environmental consequences [16-18].

Water resource security, which is considered to reflect rapid development in developing countries, has worsened in terms of quantity and quality, becoming a critical issue in UB. This issue raises the question of whether development in UB could be sustainable in the face of limited water resources and degrading environmental quality [19-22]. Studies of water resources in UB have focused mainly on groundwater availability [23-28], and limited information is available on water quality in this city. High levels of $U$ in groundwater (mean concentration: $4.6 \mu \mathrm{g} / \mathrm{L}$ ) originating from local geogenic sources have been reported [29]. In addition, the influence of land use on groundwater quality in UB was recently assessed [30]. In this study, we evaluated sustainability in UB from the perspective of water quality issues by gaining a scientific understanding of the interactions between the Tuul River and aquifer groundwater and determining the spatio-temporal variation in the concentration of $\mathrm{NO}_{3}$, the most common pollutant in areas without proper waste treatment systems, in the water system.

\section{Methods}

\subsection{Study Area}

UB is located in central Mongolia $\left(47^{\circ} 55^{\prime} 12 \mathrm{~N}, 106^{\circ} 55^{\prime} 12 \mathrm{E}\right)$, which is a continental country with a cold, semi-arid climate (Figure 1). The mean altitude is about $1350 \mathrm{~m}$ a.s.l. [31]. UB relies on groundwater drawn from the alluvial aquifer along the Tuul River, where a bank filtration system is operated [7]. The city pumps groundwater at an average rate of $150,000 \mathrm{~m}^{3} /$ day to supply inner-city residences and industries [4]. By contrast, residents living on the outskirts of the city in Ger districts use hand-dug wells as independent sources of water or purchase water at kiosks that function as local distribution centers for water pumped from the alluvial aquifer [7]. 


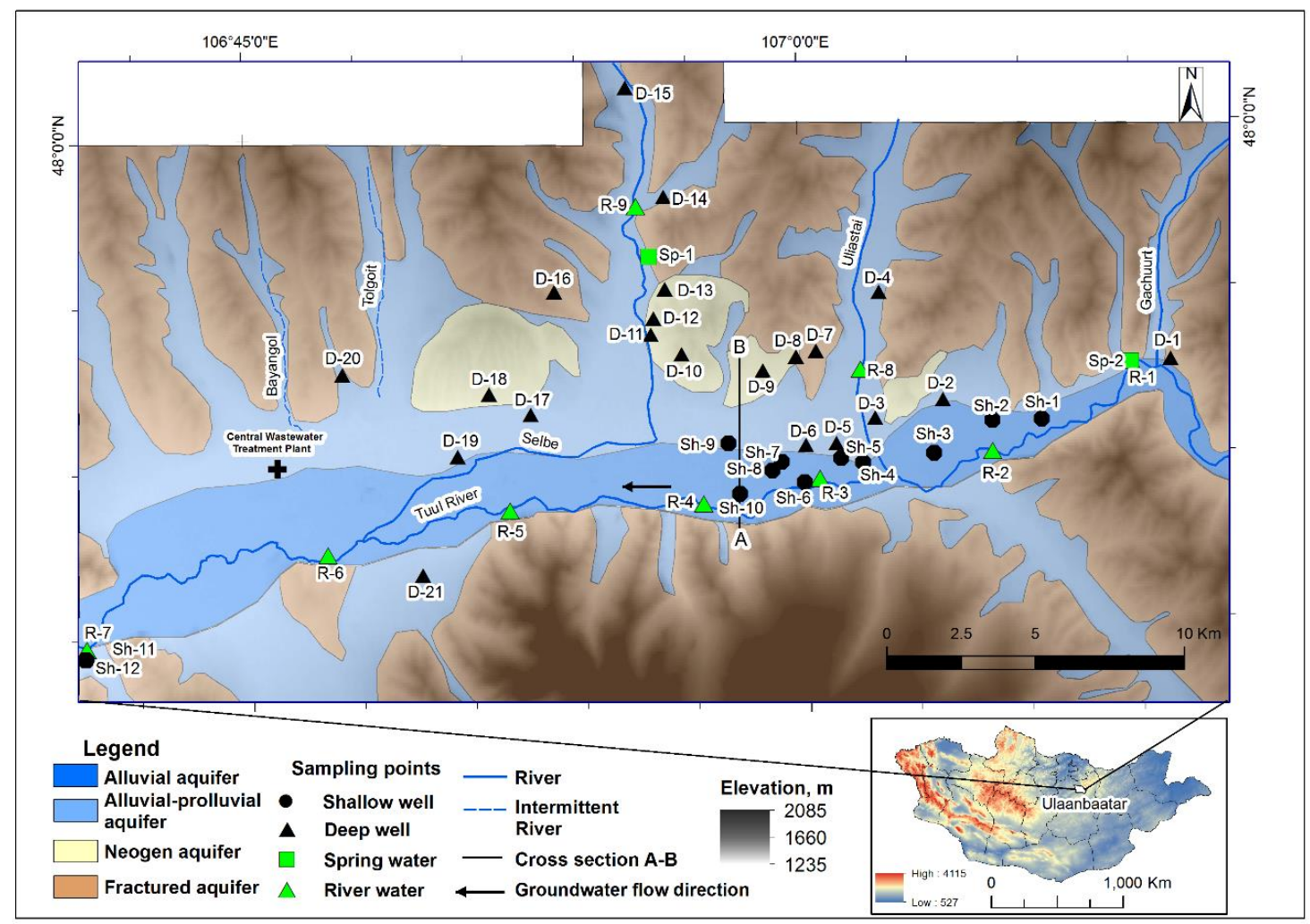

Figure 1. Hydrogeological map of Ulaanbaatar (UB) and the sampling locations (modified from a 1:200,000 hydrogeological map [10]).

The Tuul River originates in the Khentii Mountains and generally flows from north-east to south-west in a variably meandering channel. Its total length is $704 \mathrm{~km}$, with a total catchment area of $49,840 \mathrm{~km}^{2}$. The continental climatic features are characterized by wide variation in annual, monthly, and daily temperatures with cold, long winters and warm summers. About $74 \%$ of the annual precipitation falls during summer, from June to August. During winter (November-March), the ground is frozen, and precipitation accumulates as snow. Snow usually falls between mid-October and mid-April. In winter months, thick snow covers the surrounding mountains, which remain covered until early April. The annual average air temperature is $-1.2^{\circ} \mathrm{C}$; the temperature reaches the minimum of $-39.6{ }^{\circ} \mathrm{C}$ in January and the maximum of $34.5^{\circ} \mathrm{C}$ during summer [13]. The width of the Tuul River around UB is about $35 \mathrm{~m}$; however, it is reduced to $5-18 \mathrm{~m}$ in the dry season. Average depth of the river is about $1.3 \mathrm{~m}$ from May to Nov., with the most shallow during March to April (about $0.6 \mathrm{~m}$ ) and the deepest of $2.1 \mathrm{~m}$ in July 1993. The surface water in UB is partially to completely frozen from December to February. The flow begins gradually in spring (March), and discharge increases gradually to a maximum in the rainy season (July-August) $[6,7,10,28]$.

The geological features of the study area consist mainly of Devonian and Carboniferous sedimentary rocks of very low permeability intruded by granite, characterized as the basement rock (Figure 2). This basement rock is overlain by Cretaceous sandstone and mudstone, clay and sand of Neogene deposits, and Quaternary sand and gravel deposits. Quaternary deposits are also distributed widely throughout the Tuul River Basin [6,32]. 


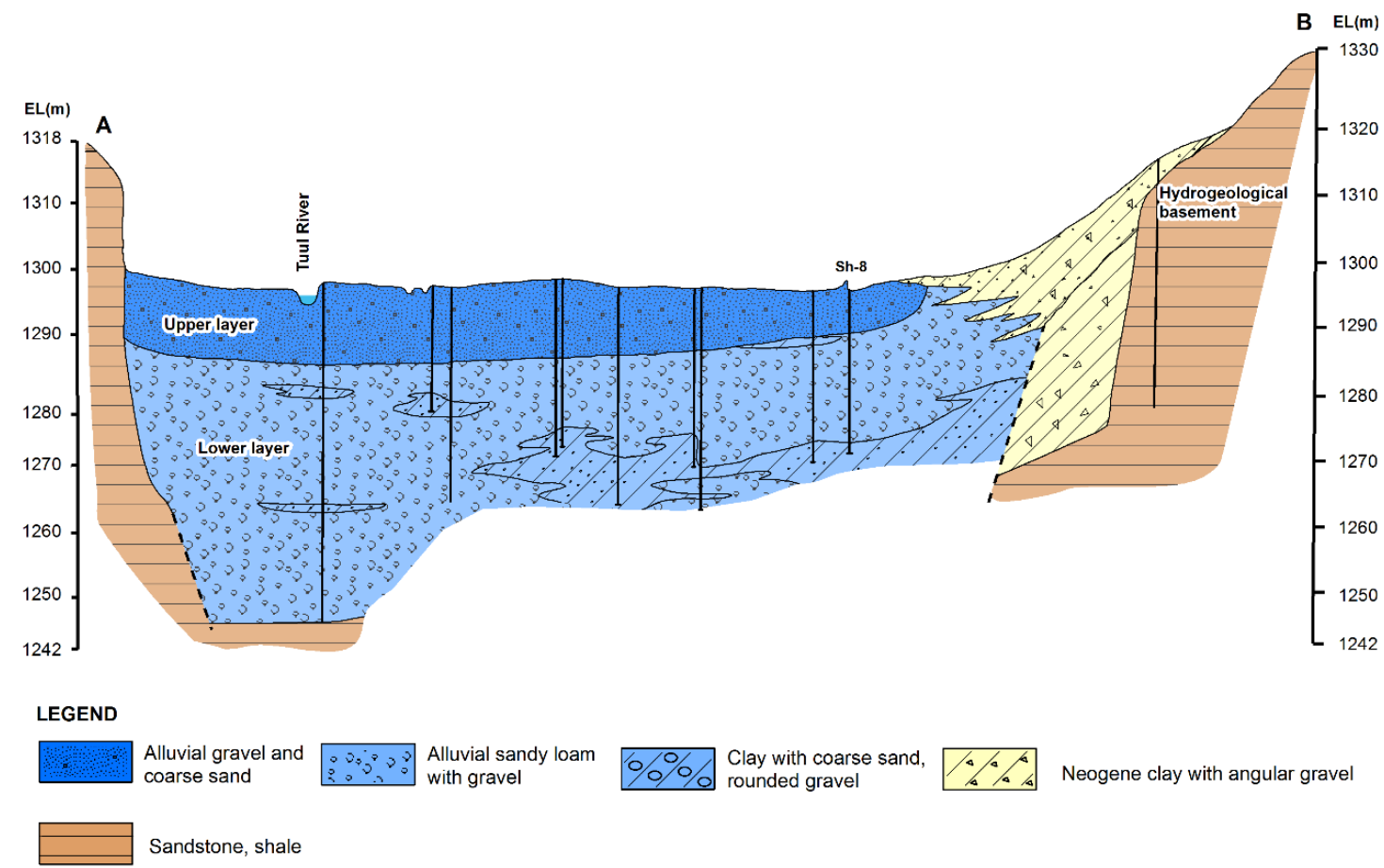

Figure 2. Hydrogeological cross-section of the alluvial aquifer around Ulaanbaatar (modified from [24]).

The alluvial aquifer is composed of sediments forming two unconfined layers, which differ primarily in composition, porosity, and water saturation (Figure 2). The upper layer consists mainly of unconsolidated gravel and boulders, and coarse sand fills the voids, representing $15-30 \%$ of the sediment by volume. The thickness ranges from 2 to $30 \mathrm{~m}$ (average: $25 \mathrm{~m}$ ) and generally increases toward the center of the river basin [6,33]. The lower layer extends down to the Neogene and Carboniferous deposits, with a thickness ranging from 3 to $20 \mathrm{~m}$. Its composition is similar to that of the upper layer, with occasional clay-dominant lenses. Fine silty sand and clay fill the voids between gravel and boulder particles and, in some areas, create clay layers ranging from a few centimeters to $5-8 \mathrm{~m}$ thick. Although the composition of the alluvial aquifer is generally uniform, the presence of clay-dominant soil with low permeability creates semi-confined conditions locally in some strata, where the lower layer of the aquifer yields less water compared with the overlying layer [32,34].

\subsection{Water Sample Collection and Analysis}

To gain a scientific understanding of the interaction between the Tuul River and groundwater in the aquifer and to clarify the spatio-temporal variation in $\mathrm{NO}_{3}$ concentrations in water, we used seasonal monitoring of water resources with hydrochemical and isotopic analyses and interpreted the spatio-temporal data using statistical approaches.

We collected 135 water samples from 40 sites to determine the dissolved ion composition and stable isotopic (i.e., $\mathrm{O}$ and $\mathrm{H}$ ) ratios of water. The samples were collected from bedrock wells in the Ger districts $(n=58)$, shallow wells in the alluvial aquifer $(n=44)$, the river $(n=24)$, and springs $(n=9)$. The groundwater samples were taken from drinking water wells and shallow wells tapped into the alluvial aquifer for the central public water supply in UB. Shallow wells were $<20 \mathrm{~m}$ deep, and deep bedrock wells were $>20$ m deep. Five sampling campaigns were conducted during August 2010, February 2011, October 2011, April 2012, and July 2017 to assess seasonal changes. In addition, two snow and two rain samples were collected from September to October 2010 and in July 2017, respectively. Additional precipitation data for UB from 1990 to 2001 were retrieved from the International Atomic Energy Agency database [35].

Water samples were filtered through $0.45-\mu \mathrm{m}$ membrane filters, sealed in $30-\mathrm{mL}$ polyethylene bottles, stored in an ice box, and transported to the Korean Basic Science Institute (KBSI; Daejeon, Korea) 
and Yonsei University (Seoul, Korea). They were analyzed for major ions and trace elements, including $\mathrm{Na}, \mathrm{K}, \mathrm{Ca}, \mathrm{Mg}, \mathrm{Si}, \mathrm{Fe}, \mathrm{Mn}, \mathrm{Zn}, \mathrm{Ni}, \mathrm{Cd}, \mathrm{Co}, \mathrm{Cr}, \mathrm{Cu}, \mathrm{Pb}, \mathrm{As}, \mathrm{Hg}, \mathrm{HCO}_{3}, \mathrm{Cl}, \mathrm{SO}_{4}$, and $\mathrm{NO}_{3}$, using Inductively Coupled Plasma Atomic Emission Spectroscopy (ICP-AES, JY Ultima 2; Horiba, Tokyo, Japan) at the KBSI and the Ion Chromatography (IC, model 883 Basic IC plus; Metrohm AG, Herisau, Switzerland) of Yonsei University. Levels of all trace elements were below the detection limits; therefore, they were not considered in the subsequent analyses. Isotopic signatures $\left(\delta^{18} \mathrm{O}\right.$ and $\left.\delta^{2} \mathrm{H}\right)$ were analyzed using a stable isotope ratio mass spectrometer (IsoPrime; GV Instruments Ltd., Manchester, UK) at the KBSI. All $\delta^{18} \mathrm{O}$ and $\delta^{2} \mathrm{H}$ data were reported using the conventional $\delta$ notation, according to the Vienna standard mean ocean water (V-SMOW) standard, Equation (1) as follows:

$$
\delta_{\text {sample }}=\frac{R_{\text {sample }}-R_{\text {SMOW }}}{R_{\text {SMOW }}} \times 1000(\% 0)
$$

where, $R_{\text {sample }}$ is the isotopic ratio of ${ }^{18} \mathrm{O} /{ }^{16} \mathrm{O}$ or $\mathrm{D} / \mathrm{H}$ of a water sample, and $\mathrm{R}_{\mathrm{SMOW}}$ is the isotopic ratio of ${ }^{18} \mathrm{O} /{ }^{16} \mathrm{O}$ or $\mathrm{D} / \mathrm{H}$ of the V-SMOW standard. The analytical reproducibility was $\pm 0.1 \%$ and $\pm 0.5 \%$ for $\delta^{18} \mathrm{O}$ and $\delta^{2} \mathrm{H}$, respectively.

Using the SPSS software (ver. 16.0; SPSS Inc., Chicago, IL, USA), a multivariate technique was applied to delineate the relationship of the spatial variation in water chemistry to $\mathrm{NO}_{3}$ contamination in the water. Hierarchical cluster analysis (HCA) was applied to identify groups obtaining similarity of water chemistry. Water chemistry of major ions and field parameters was used in the HCA by Wards linkage methods [36,37].

Controlling factors of the hydrogeochemistry and $\mathrm{NO}_{3}$ concentration of the water samples were inferred from the results of a principal component analysis (PCA). PCA has been used widely to analyze and obtain meaningful information about groundwater quality by extracting groups of correlated elements from the initial data set. These groups are included into principle factors, which describe processes occurring in the investigated environment. Identification of the factors allows genetic interpretation of the environment. First factor obtained explains the biggest part of variance. The following factors explain repeatedly smaller parts of variance. In addition, the factor loading shows how the factor characterizes the variables (ion concentration). High factor loadings (close to -1 or 1 ) indicate strong relationship (positive or negative) between the variable and the factor describing this variable. The factor loadings matrix was rotated to the orthogonal simple structure according to the varimax rotation technique. The result of this operation are high factor loadings obtained for the variable correlated in the factor and low factor loadings obtained for remaining variable [36,38,39]. For the HCA and the PCA analyses, data from the total of 95 groundwater and 20 river water samples obtained from August 2010 to April 2012 were used.

\section{Results and Discussion}

Various water sources, including shallow groundwater wells tapped into the unconsolidated aquifer along the Tuul River, relatively deep groundwater wells tapped into bedrock aquifers, and hand-dug wells, have been developed to meet the increasing demand in UB. We characterized the chemical compositions of these water sources.

\subsection{Hydrochemistry of Water Resources}

Table 1 presents basic statistics for the hydrochemical characteristics of the groundwater and surface water. Most hydrochemical parameters varied substantially among the surface water and groundwater samples. For example, in surface water, electrical conductivity (EC) ranged from 43 to $841 \mu \mathrm{S} / \mathrm{cm}$ and increased from the upstream to downstream areas of the city due to the accumulating influences of human activities and effluent discharge from the central wastewater treatment plant (R-7 in Figure 1). In groundwater, the EC values ranged from 65 to $2035 \mu \mathrm{S} / \mathrm{cm}$. 
Table 1. Descriptive statistics for the hydrochemical parameters of groundwater and surface water.

\begin{tabular}{ccccccccc}
\hline \multirow{3}{*}{ Parameter } & \multicolumn{3}{c}{ Ground Water $(\boldsymbol{N}=\mathbf{9 5})$} & \multicolumn{3}{c}{ River Water $(\boldsymbol{N}=\mathbf{2 0})$} \\
\cline { 2 - 9 } & Min. & Max. & Median & Std. Dev & Min. & Max. & Median & Std. Dev \\
\hline $\mathrm{EC}(\mu \mathrm{S} / \mathrm{cm})$ & 65.0 & 2035.0 & 426.0 & 424.1 & 43.0 & 841.0 & 96.0 & 182.6 \\
$\mathrm{pH}$ & 6.3 & 8.9 & 7.2 & 0.5 & 6.5 & 8.9 & 7.8 & 0.6 \\
$\mathrm{Temp} .\left({ }^{\circ} \mathrm{C}\right)$ & 1.2 & 14.9 & 5.9 & 2.5 & 1.9 & 21.4 & 8.0 & 6.0 \\
$\mathrm{HCO}_{3}(\mathrm{mg} / \mathrm{L})$ & 24.4 & 473.5 & 154.7 & 111.2 & 14.6 & 250.5 & 38.6 & 59.1 \\
$\mathrm{SO}_{4}(\mathrm{mg} / \mathrm{L})$ & $\mathrm{BDL}$ & 104.6 & 22.3 & 30.2 & 4.0 & 65.0 & 6.6 & 14.0 \\
$\mathrm{Cl}(\mathrm{mg} / \mathrm{L})$ & 0.6 & 206.1 & 7.2 & 35.3 & 0.4 & 62.4 & 1.8 & 14.9 \\
$\mathrm{NO}_{3}(\mathrm{mg} / \mathrm{L})$ & $\mathrm{BDL}$ & 305.4 & 12.0 & 65.7 & 0.1 & 6.5 & 1.3 & 1.9 \\
$\mathrm{SiO}_{2}(\mathrm{mg} / \mathrm{L})$ & 0.2 & 18.6 & 10.4 & 4.4 & $\mathrm{BDL}$ & 9.6 & 7.0 & 3.1 \\
$\mathrm{Ca}(\mathrm{mg} / \mathrm{L})$ & 7.0 & 197.1 & 48.9 & 53.2 & 6.8 & 50.9 & 11.5 & 12.8 \\
$\mathrm{Mg}(\mathrm{mg} / \mathrm{L})$ & 1.4 & 73.6 & 9.9 & 11.8 & 1.0 & 7.9 & 1.6 & 2.0 \\
$\mathrm{Na}(\mathrm{mg} / \mathrm{L})$ & 1.4 & 72.0 & 12.0 & 15.2 & 1.6 & 62.2 & 2.8 & 13.6 \\
$\mathrm{~K}(\mathrm{mg} / \mathrm{L})$ & $\mathrm{BDL}$ & 6.3 & 0.9 & 1.2 & $\mathrm{BDL}$ & 14.0 & 0.7 & 3.0 \\
\hline
\end{tabular}

BDL: below the detection limit.

Groundwater had significantly higher concentrations of most dissolved constituents, indicative of water-rock interactions along the groundwater flow path. Moreover, $\mathrm{NO}_{3}$ levels were significantly higher in groundwater (median: $12 \mathrm{mg} / \mathrm{L}$ ) than in surface water (median: $1.3 \mathrm{mg} / \mathrm{L}$ ), suggesting that $\mathrm{N}$ sources affected water quality via groundwater flow. The dominant factors controlling the groundwater hydrochemistry were extracted based on a principal component analysis of the major ion concentrations (i.e., $\mathrm{HCO}_{3}, \mathrm{SO}_{4}, \mathrm{Cl}, \mathrm{NO}_{3}, \mathrm{Ca}, \mathrm{Mg}, \mathrm{Na}, \mathrm{K}$ and $\mathrm{SiO}_{2}$; Table 2).

Table 2. Results of the principal component analysis for groundwater parameters after varimax rotation.

\begin{tabular}{ccc}
\hline Parameter & PC 1 & PC 2 \\
\hline $\mathrm{HCO}_{3}$ & 0.30 & $\underline{\mathbf{0 . 7 0}}$ \\
$\mathrm{SO}_{4}$ & 0.57 & 0.64 \\
$\mathrm{Cl}$ & $\underline{\mathbf{0 . 7 5}}$ & 0.55 \\
$\mathrm{NO}_{3}$ & $\underline{\mathbf{0 . 7 6}}$ & 0.56 \\
$\mathrm{SiO}_{2}$ & 0.04 & $\underline{\mathbf{0 . 8 7}}$ \\
$\mathrm{Ca}$ & 0.62 & $\underline{\mathbf{0 . 7 2}}$ \\
$\mathrm{Mg}$ & 0.68 & 0.63 \\
$\mathrm{Na}$ & $\underline{\mathbf{0 . 7 2}}$ & 0.42 \\
$\mathrm{~K}$ & $\underline{\mathbf{0 . 8 4}}$ & -0.03 \\
\% variance explained by eigenvalues & 67.8 & 10.0 \\
\% variance explained by squared sum of loadings & 40.4 & 37.4 \\
\hline incipal component loadings > 0.7: bold with underline; Principal Component (PC).
\end{tabular}

Principal Component (PC) 1 and 2 explained approximately $77.8 \%$ of the total variation in the hydrochemical data. PC 1, explaining about $68 \%$ of the variance, included the influences of $\mathrm{K}_{1} \mathrm{NO}_{3}$, $\mathrm{Cl}$, and $\mathrm{Na}$. Of these parameters, $\mathrm{NO}_{3}$ and $\mathrm{Cl}$ could be explained by groundwater contamination in urban areas without proper sewage systems. The highest factor loading of $\mathrm{K}$ might have originated from detergent in wastewater, which is a source of $\mathrm{Cl}$ and $\mathrm{K}$ [40]. PC 2 accounted for another $10 \%$ of the total variance, and predominantly included the influences of $\mathrm{SiO}_{2}, \mathrm{Ca}$, and $\mathrm{HCO}_{3}$. These ions reflected natural water-rock interactions, characterized by weathering of silicate and carbonate minerals in the local aquifer system. Consequently, the groundwater chemistry and quality in the study area appeared to be controlled by anthropogenic pollution overlapping natural water-rock interactions.

To delineate the spatial distribution of water quality based on the potential for $\mathrm{NO}_{3}$ pollution, we employed a hierarchical cluster analysis (HCA) $[36,37]$ to identify groups with similar major ion compositions and field parameters. Figure 3 presents a tree diagram produced from the HCA, which divides the samples into three groups. Most shallow groundwater samples from the alluvial aquifer were clustered in Group 1 (Sh-1-Sh-12, D-15, and D-21). Group 2 included spring water 
(Sp-1) and bedrock groundwater (D-1, -2, -3, -4, -8, -9, -14, and -19). Finally, Group 3 accounted for the remaining bedrock groundwater and spring samples (D-6, -7, -10, -11, -16, -17, -18, -20, and Sp-1).

Rescaled distance (between groups)

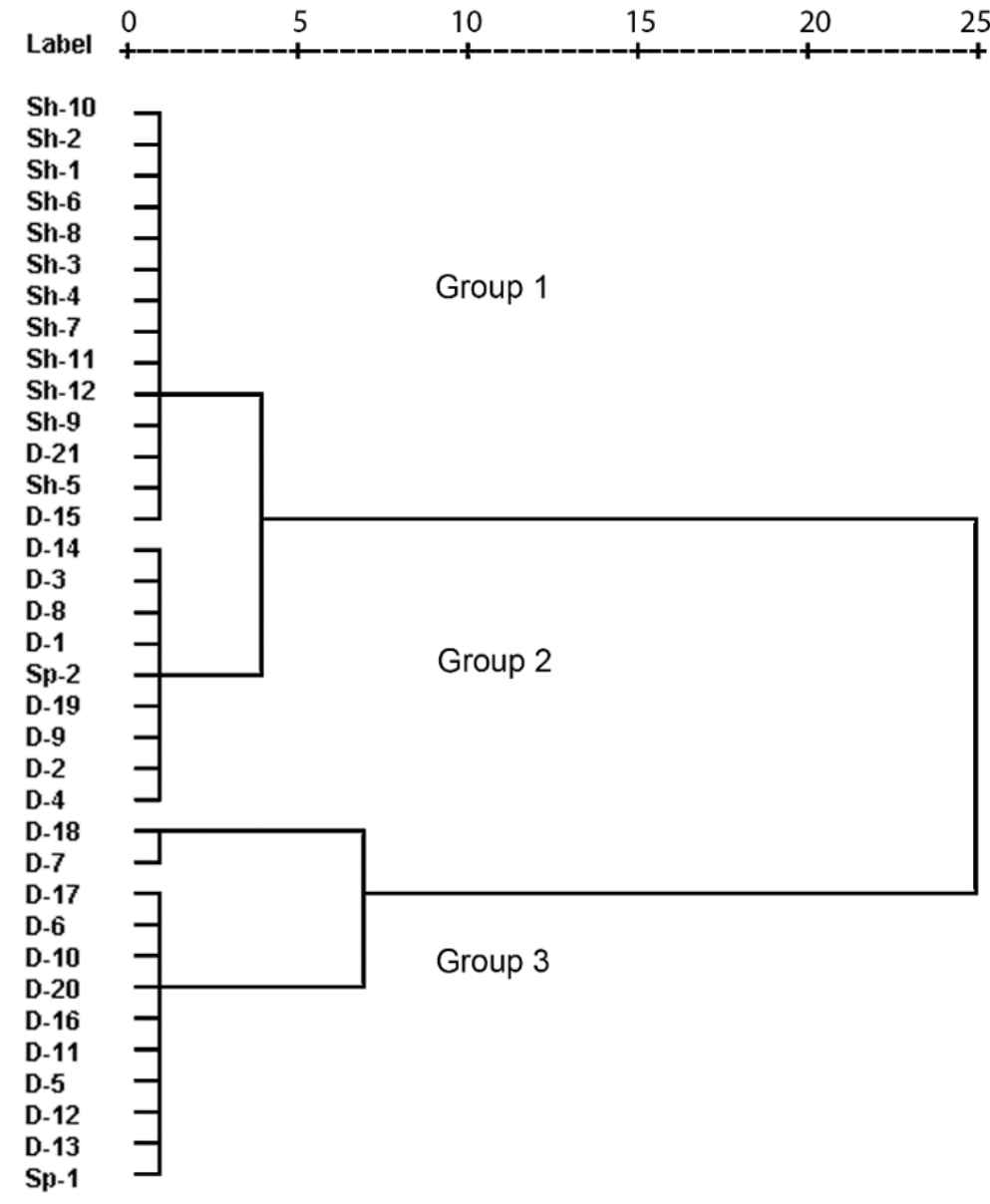

Figure 3. Dendrogram of the groundwater sample groups based on their hydrochemical properties.

Based on Gibbs' [41] plots (Figure 4), water-rock interactions appeared to be the major mechanism controlling the hydrochemistry of water in UB for shallow alluvial aquifer and bedrock aquifer groundwater, as well as river water. All resources had similar $\mathrm{Na} /(\mathrm{Na}+\mathrm{Ca})$ ratios; however, they were clearly differentiated based on the TDS concentrations, which were higher for resources with longer residence times. Group 1 groundwater and river water samples were characterized by similar ranges of TDS, $\mathrm{Na} /(\mathrm{Na}+\mathrm{Ca})$, and $\mathrm{Cl} /\left(\mathrm{Cl}+\mathrm{HCO}_{3}\right)$, implying vigorous interchange. TDS and $\left.\mathrm{Cl} /(\mathrm{Cl}+\mathrm{HCO})\right)$ values for groundwater samples showed increasing trends from Group 1 to Groups 2 and 3. 

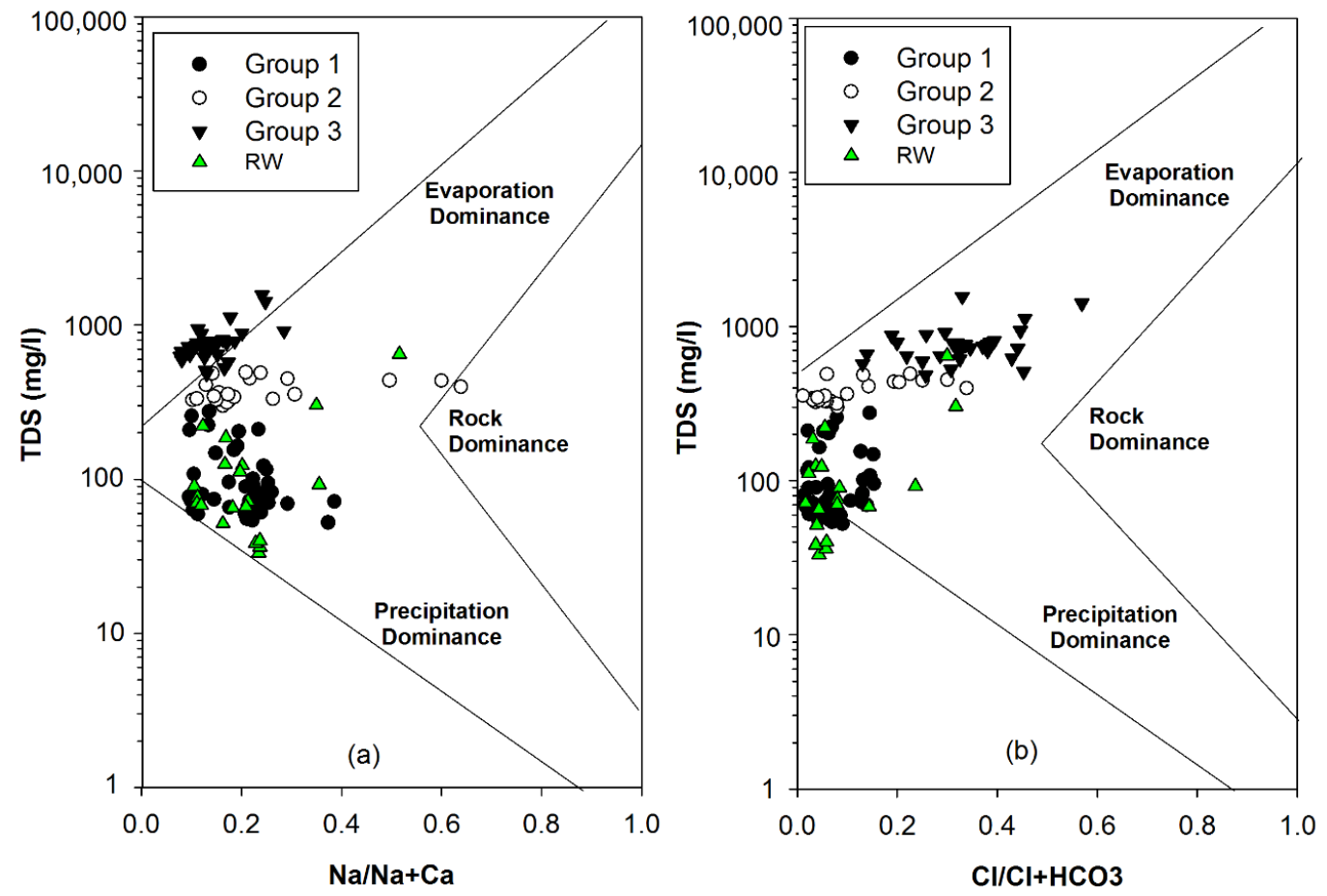

Figure 4. Variation in the $\mathrm{Na} /(\mathrm{Na}+\mathrm{Ca})$ and $\mathrm{Cl} /\left(\mathrm{Cl}+\mathrm{HCO}_{3}\right)$ ratios $(w / w)$ as a function of the total dissolved solids (TDS) in the water resources (adapted from [41]).

The hydrochemical compositions of the water samples plotted on the modified Piper diagram indicated gradual changes in water chemistry and quality from $\mathrm{Ca}-\mathrm{HCO}_{3}$-type to $\mathrm{Ca}-\left[\mathrm{HCO}_{3}+\mathrm{Cl}\right.$ $\left.+\mathrm{NO}_{3}\right]$-type water (Figure 5). Surface waters were predominantly of the $[\mathrm{Ca}+\mathrm{Na}]-\mathrm{HCO}_{3}$ type, similar to Group 1 groundwater samples from the riverbank area. Group 1 groundwater samples were typically of the $\mathrm{Ca}-\mathrm{HCO}_{3}$ type, whereas Group 2 samples were categorized more broadly as being of the $[\mathrm{Ca}+\mathrm{Na}]-\left[\mathrm{HCO}_{3}+\mathrm{Cl}\right]$ type. Group 3 samples were typically of the $\mathrm{Ca}-\left[\mathrm{Cl}+\mathrm{NO}_{3}\right]$ type, probably reflecting the influence of the anthropogenic input of $\mathrm{Cl}$ and $\mathrm{NO}_{3}$.

Figure 6 shows the distribution of the groundwater hydrochemical characteristic groups. Group 1 wells, distributed along the Tuul River, were mostly shallow wells tapped into the alluvial aquifer. Group 2 wells are distributed along the east-western side of the study area between Group 1 and Group 3. Finally, Group 3 wells, on the north-central side of UB, were bedrock wells and springs characterized by water-rock interactions in the bedrock aquifer. In Group 3, the impact of the Ger districts on the slope is probably exemplified, which lack proper sewage disposal systems. 


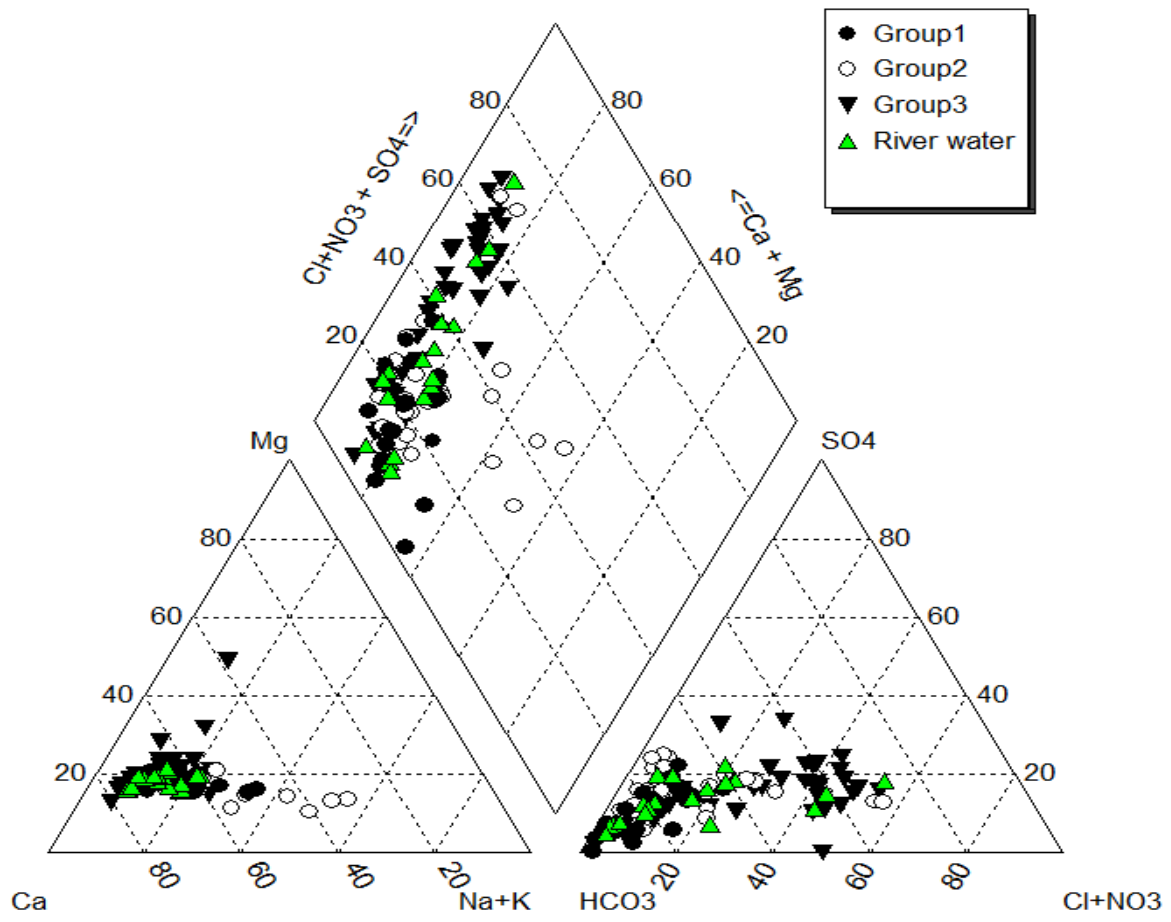

Figure 5. Piper diagrams of the chemical compositions of groundwater and surface water in UB.

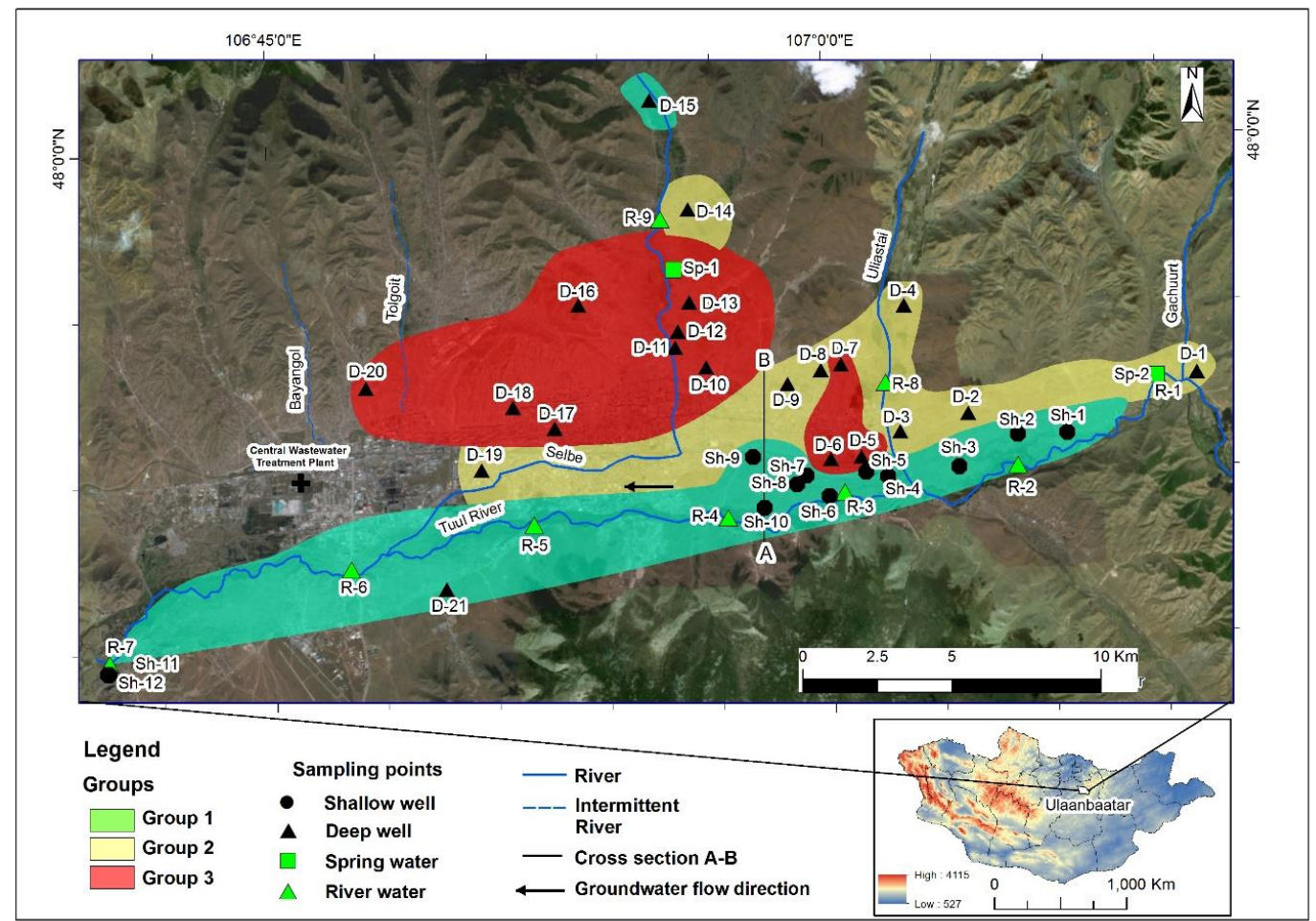

Figure 6. Spatial distribution of the groundwater well groups with different hydrochemical characteristics in the study area.

Based on the factor analysis (Table 2), the dominant water-rock interactions were related to silicate and carbonate weathering and dissolution-precipitation processes [42,43]. The Group 1 groundwater samples were plotted below the $\mathrm{HCO}_{3}$ versus $\mathrm{SiO}_{2}$ 10:1 slope (Figure 7a), indicating that silicate 
weathering was the dominant process. As these wells were tapped into the upper layer of alluvium distributed along the Tuul River, silicate weathering could occur in the coarse to fine sands and gravels derived from shale, quartz sandstone, and granite [24]. By contrast, groundwater and even surface water samples from Groups 2 and 3 were plotted above the 10:1 slope, indicating that carbonate weathering was the dominant process. We used the $\mathrm{HCO}_{3}$ versus $\mathrm{Ca}$ concentration plot of the samples to assess the dissolution and precipitation of carbonate minerals (Figure 7b). Group 3 wells exhibited stronger $\mathrm{CaCO}_{3}$ dissolution than $\mathrm{CaCO}_{3}$ precipitation, whereas Group 2 wells showed the opposite trend. These results imply that more freshwater recharge occurred in Group 3 wells than in Group 2 wells, suggesting that they are exposed to the risk of pollution from near-surface sources.
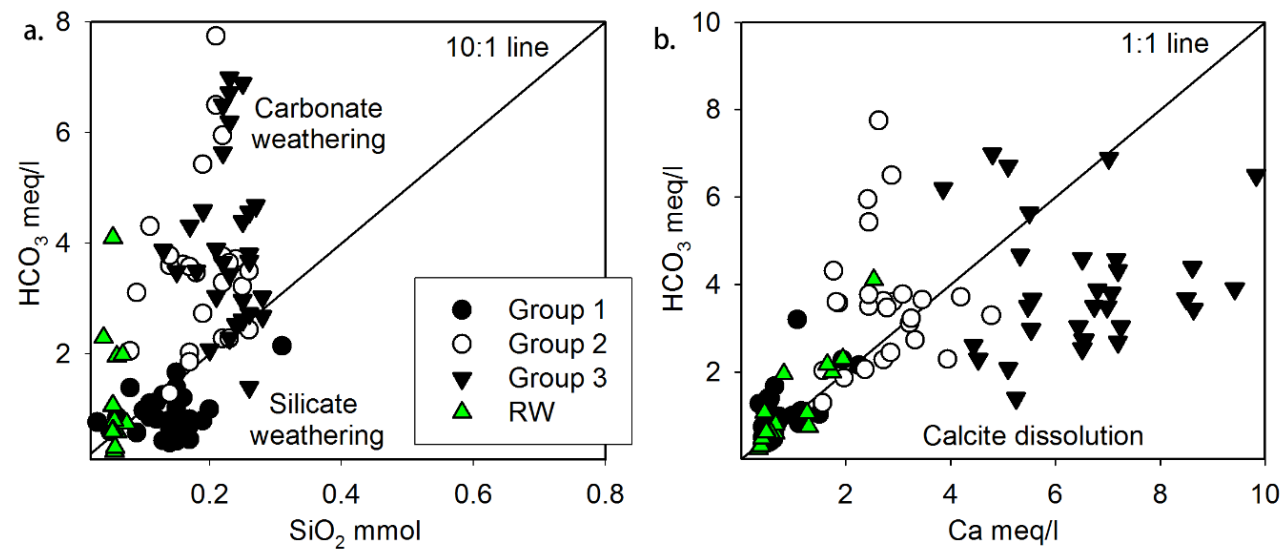

Figure 7. Assessment of the dominant water-rock interactions of the water samples plotted based on (a) $\mathrm{HCO}_{3}$ vs. $\mathrm{SiO}_{2}$ and (b) $\mathrm{HCO}_{3}$ vs. $\mathrm{Ca}^{2+}$ concentrations.

In summary, water in UB could be differentiated into three groups based on its hydrochemical characteristics. Group 1 samples were located along the Tuul River, Group 2 samples were from the north-eastern area of UB, and Group 3 samples were from the north-western area. Group 1 included the alluvial aquifer along the river and showed silicate weathering-dominant water-rock interactions. By contrast, samples from Groups 2 and 3 reflected predominantly carbonate weathering. However, Group 3 was under the influence of $\mathrm{CaCO}_{3}$ dissolution conditions, indicative of more freshwater recharge, making it more vulnerable than Group 2 to surface pollution sources.

\subsection{Isotopic Signatures of Water Resources}

The relationships among various water sources (i.e., precipitation, surface water, and groundwater) were inferred based on isotopic signatures $\left(\delta^{18} \mathrm{O}\right.$ and $\left.\delta^{2} \mathrm{H}\right)$. Precipitation isotopic data were obtained from 1990 to 2001 [35]. $\delta^{18} \mathrm{O}$ ranged from $-30.4 \%$ to $-1.6 \%$ (median: $-11.5 \%$ ), and $\delta^{2} \mathrm{H}$ ranged from $-236.5 \%$ to $-16.6 \%$ (median: $-81.4 \%$; Figure 8 ). From these data, the local meteoric water line (LMWL) was defined as Equation (2).

$$
\delta^{2} \mathrm{H}=7.8 \delta^{18} \mathrm{O}+2.7\left(r^{2}=0.98\right)
$$

The slope of the LMWL was 7.8, which was close to the equilibrium value of 8.0 [44]. The intercept of the LMWL was 2.7, much lower than the global meteoric water line value of 10, indicative of lower deuterium excess values in the warm season due to the evaporation effect of summer precipitation [45-48]. The long-term precipitation data showed seasonal differences in isotopic values, with higher values in summer than in winter (Figure 8a). Such seasonal variation has been reported as an effect of temperature, as precipitation under warmer temperatures condenses with heavier isotopes due to evaporation during rainfall, and consequently has higher isotopic compositions than does precipitation under colder conditions [49,50]. All median isotopic signatures of the groundwater and surface water samples were lower than the weighted median precipitation, indicating that groundwater and surface 
water, which provide the main water supply for the city, are likely recharged from present-day meteoric water.
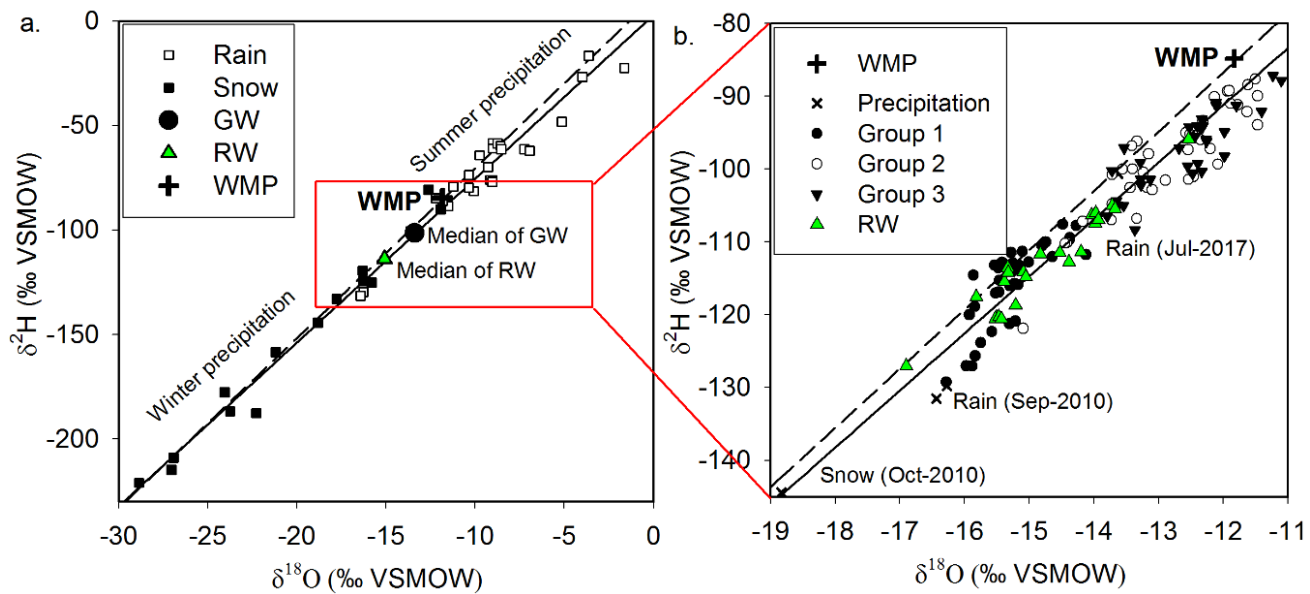

Figure 8. $\delta^{18} \mathrm{O}$ and $\delta^{2} \mathrm{H}$ values of water in the study area: (a) precipitation from 1990 to 2001 (data obtained from [35]) and (b) water sample groups of this study from 2010 to 2017. WMP indicates the weighted median precipitation of UB, and the Global Meteoric Water line (GMWL) and Local Meteoric Water line (LMWL) are presented as solid and dotted lines, respectively. GW and RW denote groundwater and river water, respectively.

The $\delta^{18} \mathrm{O}$ and $\delta^{2} \mathrm{H}$ values of the groundwater and surface water samples ranged widely from $-16.9 \%$ to $-11.1 \%$ and $-129.3 \%$ to $-87.2 \%$, respectively (Table 3 ). The $\delta^{18} \mathrm{O}$ and $\delta^{2} \mathrm{H}$ values in river water ranged from $-16.9 \%$ to $-12.5 \%$ and $-127.0 \%$ to $-96.0 \%$, respectively (Figure $8 b$ ). The Group 1 groundwater samples from the alluvial aquifer close to the Tuul River had $\delta^{18} \mathrm{O}$ and $\delta^{2} \mathrm{H}$ values of $-16.3 \%$ to $-13.2 \%$ and $-129.3 \%$ o to $-100.0 \%$, respectively. Meanwhile, the $\delta^{18} \mathrm{O}$ and $\delta^{2} \mathrm{H}$ values of the Group 2 samples ranged from $-14.4 \%$ to $-11.5 \%$ and $-110.2 \%$ to $-87.7 \%$, respectively. Finally, those of Group 3 groundwater samples ranged from $-13.7 \%$ o to $-11.1 \%$ ond $-108.4 \%$ o to $-87.2 \%$, respectively. Group 1 shallow groundwater samples were relatively depleted in isotopic ratios compared with the bedrock groundwater in Groups 2 and 3, but their values were similar to those of surface water. These results suggest that bedrock groundwater experienced a relatively longer residence period under the influence of evaporation along the flow paths from the land surface to the local groundwater discharge points $[51,52]$.

Table 3. $\delta^{2} \mathrm{H}$ and $\delta^{18} \mathrm{O}$ values of the water resources (unit: \%o).

\begin{tabular}{|c|c|c|c|c|c|c|c|c|c|}
\hline \multirow{2}{*}{\multicolumn{2}{|c|}{ Water Resource }} & \multicolumn{4}{|c|}{$\delta^{18} \mathrm{O}$} & \multicolumn{4}{|c|}{$\delta^{2} \mathbf{H}$} \\
\hline & & Min. & Max. & Median & Std. Dev. & Min. & Max. & Median & Std. Dev. \\
\hline \multirow{2}{*}{\multicolumn{2}{|c|}{$\begin{array}{l}\text { Precipitation } \\
\text { River water }\end{array}$}} & -30.5 & -1.6 & -11.5 & 7.5 & -236.5 & -16.6 & -81.4 & 59 \\
\hline & & -16.9 & -12.5 & -15.1 & 0.9 & -127 & -96 & -113.9 & 6.8 \\
\hline \multirow{3}{*}{ Groundwater } & Group 1 & -16.3 & -13.2 & -15.3 & 0.7 & -129.3 & -100 & -113.5 & 6.5 \\
\hline & Group 2 & -14.4 & -11.5 & -12.5 & 0.9 & -110.2 & -87.7 & -97.3 & 6.3 \\
\hline & Group 3 & -13.7 & -11.1 & -12.4 & 0.7 & -108.4 & -87.2 & -96.7 & 5.3 \\
\hline
\end{tabular}

As the groundwater discharged into the river through the shallow alluvial aquifer, these two sources mixed dynamically with river water, which has lower isotopic signatures, via pumping effects. River water can become isotopically depleted due to high-intensity rainfall [51], recharge from upstream highland areas due to altitude effects, or snowmelt water inflow [49]. Considering that UB is surrounded by high mountains and has a dry climate, the low isotopic values in the Tuul River could be the result of snowmelt input in upstream areas. Group 2 groundwater was not clearly distinguished 
from that of Group 3, probably because the wells of these groups were located in geographically similar areas on slopes, resulting in similar groundwater flow paths.

In summary, the stable isotopic signatures of the water sources in UB exhibited various fractionation effects, including seasonal variation in long-term changes and evaporation via altitude effects. The isotopic values of groundwater and surface water indicate that they are of meteoric origin. Due to pumping-induced recharge, the shallow groundwater from the alluvial aquifer along the Tuul River appeared to mix dynamically with river water originating from the upstream area fed by snowmelt water. The bedrock groundwater samples from wells of Groups 2 and 3 showed normal hydrological cycles of precipitation transferring to infiltration, evaporation, recharge, and discharge into the Tuul River.

\subsection{Nitrate Contamination of Water Resources}

$\mathrm{NO}_{3}$ in water resources can originate from various sources, including atmospheric deposition, chemical and organic fertilizers, industrial waste effluent, and improperly maintained septic systems [53]. Natural $\mathrm{NO}_{3}$ levels in groundwater are generally very low $\left(<10 \mathrm{mg} / \mathrm{L} \mathrm{NO}_{3}\right)$, but these levels can increase in association with anthropogenic inputs. In urban areas, $\mathrm{NO}_{3}$ concentrations are often above $50 \mathrm{mg} / \mathrm{L}$, reflecting $\mathrm{N}$ loading from high-density housing without sewage sanitation systems [54]. As such, $\mathrm{NO}_{3}$ is the most common water pollutant, and causes significant health issues associated with water resource use. The World Health Organization has established a drinking-water $\mathrm{NO}_{3}$ guideline level of $50 \mathrm{mg} / \mathrm{L}$ based on health concerns [55]. However, $\mathrm{NO}_{3}$ concentrations of 10-20 mg/L have been linked to health effects; Ward et al. [56] reported that long-term exposure to such $\mathrm{NO}_{3}$ levels from municipal water supply systems has possible links to bladder and ovarian cancers and non-Hodgkin's lymphoma in the United States [56,57].

In the water samples from $\mathrm{UB}, \mathrm{NO}_{3}$ concentrations ranged from below the detection limit to $305.4 \mathrm{mg} / \mathrm{L}$ (Table 4). River water samples showed no indication of $\mathrm{NO}_{3}$ pollution (median: $1.1 \mathrm{mg} / \mathrm{L}$ ) and the 48 shallow groundwater samples from the alluvial aquifer along the Tuul River in Group 1 also appeared to have background levels with maximum of $5.18 \mathrm{mg} / \mathrm{L}$. Several exceptions were found in shallow dug well Sh-5 and municipal monitoring wells Sh-9 and D-21, showing potential pollution risks indicated by higher ranges from BDL to $27.8 \mathrm{mg} / \mathrm{L}$. Groundwater from Group 2 wells had $\mathrm{NO}_{3}$ concentrations of $8.0-47.4 \mathrm{mg} / \mathrm{L}$ (median: $15.8 \mathrm{mg} / \mathrm{L}$ ), implying that these wells were influenced by $\mathrm{NO}_{3}$ contamination sources, although the $\mathrm{NO}_{3}$ levels were within the drinking-water guideline. By contrast, Group 3 groundwater samples, with $\mathrm{NO}_{3}$ concentrations of 64.0-305.4 mg/L (median: $101.3 \mathrm{mg} / \mathrm{L}$ ), were highly contaminated. Wells in Groups 2 and 3 comprised $25 \%$ and $32 \%$ of the sampled wells, respectively, indicating that about $60 \%$ of the groundwater in the study area could be under the influence of $\mathrm{NO}_{3}$ contamination sources.

Table 4. Distribution of $\mathrm{NO}_{3}$ concentrations in various water resources in UB (unit: $\mathrm{mg} / \mathrm{L}$ ).

\begin{tabular}{|c|c|c|c|c|c|c|}
\hline \multicolumn{2}{|c|}{ Water Resource } & \multirow{2}{*}{$\begin{array}{c}\text { Number of Samples } \\
48\end{array}$} & \multirow{2}{*}{$\frac{\text { Min. }}{\text { BDL }}$} & \multirow{2}{*}{$\begin{array}{r}\text { Max. } \\
27.8\end{array}$} & \multirow{2}{*}{$\frac{\text { Median }}{1.7}$} & \multirow{2}{*}{$\frac{\text { Std. Dev. }}{6}$} \\
\hline & Group 1 & & & & & \\
\hline Groundwater & Group 2 & 28 & 8 & 47.4 & 15.8 & 11 \\
\hline & Group 3 & 35 & 64 & 305.4 & 101.3 & 57.8 \\
\hline \multicolumn{2}{|c|}{ River water } & 24 & BDL & 6.5 & 1.1 & 1.8 \\
\hline
\end{tabular}

BDL: below the detection limit.

Groundwater $\mathrm{NO}_{3}$ sources were delineated based on the hydrochemistry of the water samples. Figure 9a presents the $\mathrm{Na}$ versus $\mathrm{Cl}$ concentrations of the water samples, where a slope of 1:1 indicates that $\mathrm{Na}$ and $\mathrm{Cl}$ originate from meteoric sources [53]. Most surface water samples and Groups 1 and 2 groundwater samples were plotted below the 1:1 slope line, indicative of excess $\mathrm{Na}$ ions from the geological matrix. Silicate mineral weathering could account for the additional $\mathrm{Na}$ in the surface water and Group 1 groundwater (Figure 7a) [58]. Meanwhile, for Group 2 groundwater, dominated by carbonate weathering, cation exchange processes could account for the additional $\mathrm{Na}$ from the geologic 
matrix via Ca substitution (Figure $7 \mathrm{~b}$ ). By contrast, the excess $\mathrm{Cl}$ concentrations in Group 3 groundwater appeared to originate from the same sources as $\mathrm{NO}_{3}$ (Figure $9 \mathrm{~b}$ ).
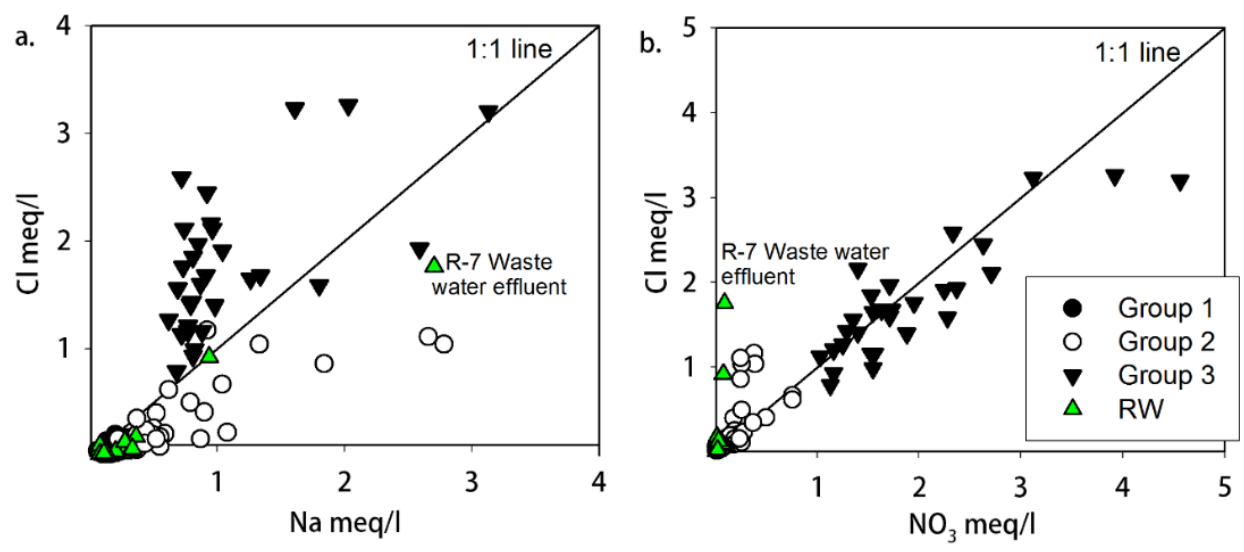

Figure 9. Relationships of (a) $\mathrm{Na}$ vs. $\mathrm{Cl}$ and (b) $\mathrm{NO}_{3}$ vs. $\mathrm{Cl}$ in various water resources.

During the rapid development of UB over the last decade, population growth has surpassed that of the city's infrastructure, and Ger districts have expanded to surround the city center. Given the lack of proper infrastructure (e.g., pipeline water-distribution systems and sewage disposal systems), groundwater wells, such as those in Groups 2 and 3, have become the main sources of water for residents through water kiosks. At the same time, the groundwater developed along the slope areas has become threatened by contamination sources, including unmanaged pit latrines and septic tanks [55]. The correlation between high $\mathrm{NO}_{3}$ concentrations and heavier isotopic values in groundwater (Figure 10) indicates that these sources could become contaminated in the Ger districts. Ultimately, contaminated groundwater from the upslope recharge area flows downward toward the discharge area, the Tuul River, slowly and steadily expanding the region impacted by contamination to the riverbank alluvial aquifer, threatening the shallow groundwater, which is the major water supply for the city center.

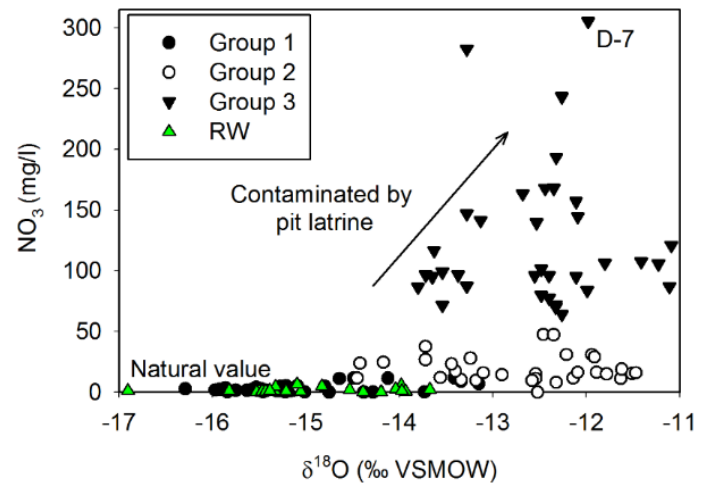

Figure 10. Identification of source areas of groundwater contamination based on a plot of $\mathrm{NO}_{3}$ vs. $\delta^{18} \mathrm{O}$.

Figure 11 presents the results of the seasonal sampling campaigns. In Group 1, the $\mathrm{NO}_{3}$ concentration was stable, with the lowest median value of $1.7 \mathrm{mg} / \mathrm{L}$. This value likely represents the natural $\mathrm{NO}_{3}$ concentration in alluvial aquifer groundwater, which actively interacts and mixes with the Tuul River. By contrast, the median $\mathrm{NO}_{3}$ levels in Group 2 wells ranged from 15.9 to $27.7 \mathrm{mg} / \mathrm{L}$, with no significant temporal variation. The most contaminated groundwater, from the Group 3 wells, showed relatively wide variation among the sampling periods. The highest median value was observed during late summer in October 2011, and the lowest value was observed during winter in February 2011. In river water samples, highest nitrate levels were also recorded in October 2011 with 
high rainfalls, but low in July 2017 without much rainfall. This implies that nitrate levels in the river water could be affected by introduction of $\mathrm{NO}_{3}$ sources through direct surface runoff from the areas of Group 3 wells that are exposed to the same sources by recharge processes. In summary, the wide variation in $\mathrm{NO}_{3}$ concentrations during each campaign suggest that the degree of contamination varies significantly on a spatial scale, probably due to local sources of contamination. In addition, seasonal changes of nitrate background levels of the River water and the Group 3 seem to be affected by rainfall, more seasonal data should be obtained to identify any significant trends.
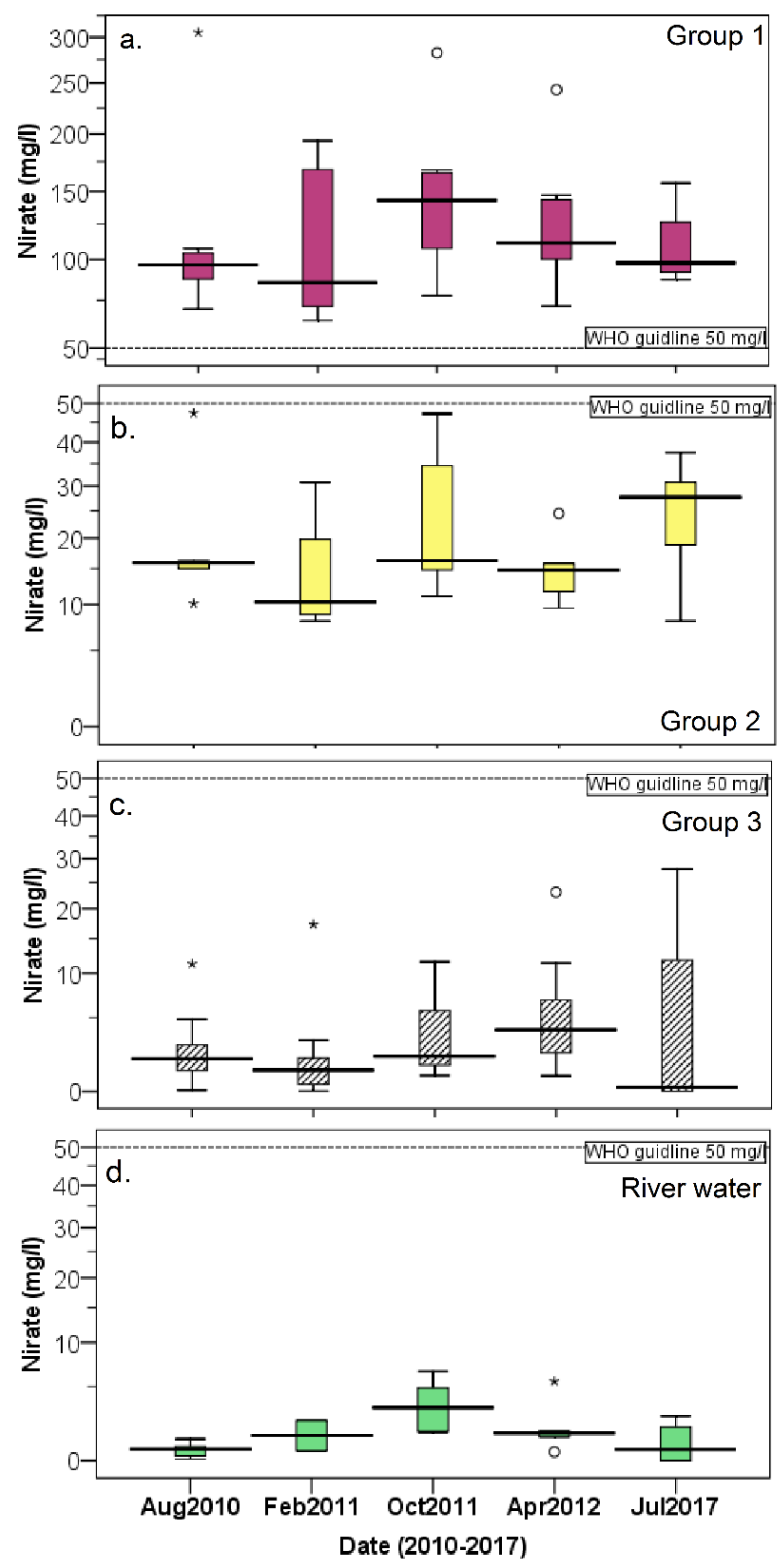

Figure 11. Box plot showing the $\mathrm{NO}_{3}(\mathrm{mg} / \mathrm{L})$ concentration (including the standard deviation, minimum, maximum, and median values) during sampling campaigns from 2010 to 2017. $\mathrm{NO}_{3}$ concentrations are presented on a power of the exponent scale (0.5); (a) Group 3, (b) Group 2, (c) Group 1, and (d) River water, respectively. " $* *$, "o" denotes outliers.

\section{Conclusions}

UB is one of the fastest growing cities worldwide. However, its rapid urbanization has surpassed urban infrastructure development (e.g., sewage disposal systems), posing a significant 
risk of water pollution. Therefore, we evaluated the sustainability of UB from the perspective of water-resource quality issues. Based on five sampling campaigns and hydrochemical and isotopic analyses of various water samples from the Tuul River, shallow groundwater from the alluvial aquifer, bedrock groundwater, springs, and precipitation, we came to the following conclusions:

1. The hydrochemistry of the water samples from various resources is typically dependent on two major factors: $\mathrm{NO}_{3}$ contamination processes and mineral weathering processes according to water-rock interactions of carbonate and silicate minerals in the geologic matrix.

2. Based on their chemical composition, the groundwater samples could be classified into three groups. Group 1 included shallow groundwater from the alluvial aquifer distributed along the Tuul River, exhibiting silicate weathering-dominant water-rock interactions with near-natural $\mathrm{NO}_{3}$ concentrations. Group 2 samples, distributed mostly on the north-eastern side of the study area, appeared to reflect carbonate hydrochemical reactions of carbonate weathering, as they had intermediate $\mathrm{NO}_{3}$ levels. Group 3 samples were dominated by $\mathrm{CaCO}_{3}$ dissolution, probably due to freshwater recharge, and had significantly elevated $\mathrm{NO}_{3}$ levels exceeding the World Health Organization drinking water guideline of $50 \mathrm{mg} / \mathrm{L}$.

3. The correlation of $\mathrm{NO}_{3}$ with $\mathrm{Cl}$ in the groundwater samples and the isotopic signatures implied that $\mathrm{NO}_{3}$ in groundwater resources originated from unsuitable sanitary and sewage disposal practices in the Ger districts, typically located in the upstream area surrounding UB with dense and poor living conditions.

4. The stable isotope signatures delineated the typical groundwater flow in UB. Precipitation recharges into bedrock groundwater in the upslope area, flows downward, and eventually discharges to the local base level of the basin, the Tuul River, through the alluvial aquifer. In the alluvial aquifer along the river, active pumping from multiple wells using riverbank filtration drives dynamic mixing of the groundwater and river water.

5. The Tuul River and shallow groundwater from the alluvial aquifer had natural background $\mathrm{NO}_{3}$ concentrations. Meanwhile, Group 3 groundwater, accounting for $32 \%$ of the total groundwater samples, showed $\mathrm{NO}_{3}$ contamination, with minimum and maximum concentrations of 64.0 and $305.6 \mathrm{mg} / \mathrm{L}$, respectively. Finally, Group 2 groundwater samples had a maximum $\mathrm{NO}_{3}$ concentration of $47.4 \mathrm{mg} / \mathrm{L}$ and median of $15.8 \mathrm{mg} / \mathrm{L}$, indicating that this groundwater was influenced by anthropogenic sources.

Figure 12 presents a schematic diagram of the groundwater system and its relation to $\mathrm{NO}_{3}$ contamination of water resources. The hydrochemical characteristics and stable isotope ratios of water samples indicate that groundwater flows from the upslope area to the downslope city center toward the Tuul River through the alluvial aquifer. As the groundwater moves downward, it could carry $\mathrm{NO}_{3}$ from anthropogenic sources, slowly and steadily spreading contamination. Although Group 2 groundwater in the nearby city area has $\mathrm{NO}_{3}$ levels below the guideline of $50 \mathrm{mg} / \mathrm{L}$, its water quality will likely deteriorate in the future and warrants continuous monitoring.

As one of the fastest-growing cities worldwide, UB is facing major water supply issues, including water shortages due to over-exploitation driven by increased demand and water-quality degradation (e.g., $\mathrm{NO}_{3}$ contamination) driven by inadequate infrastructure. As identified in this study, $\mathrm{NO}_{3}$ is the major threat to water quality in UB and appears to be exerting a continuously increasing impact on water resources. In addition, rainy and dry seasonal effects appear on the water quality of river water, probably through the direct runoff from slope areas with potential sources exposed to the land surface. As water resources of adequate quality and quantity must be secured for the sustainable development of UB, appropriate institutional measures should be implemented to protect and preserve the existing water resources with systematic spatio-temporal monitoring. 


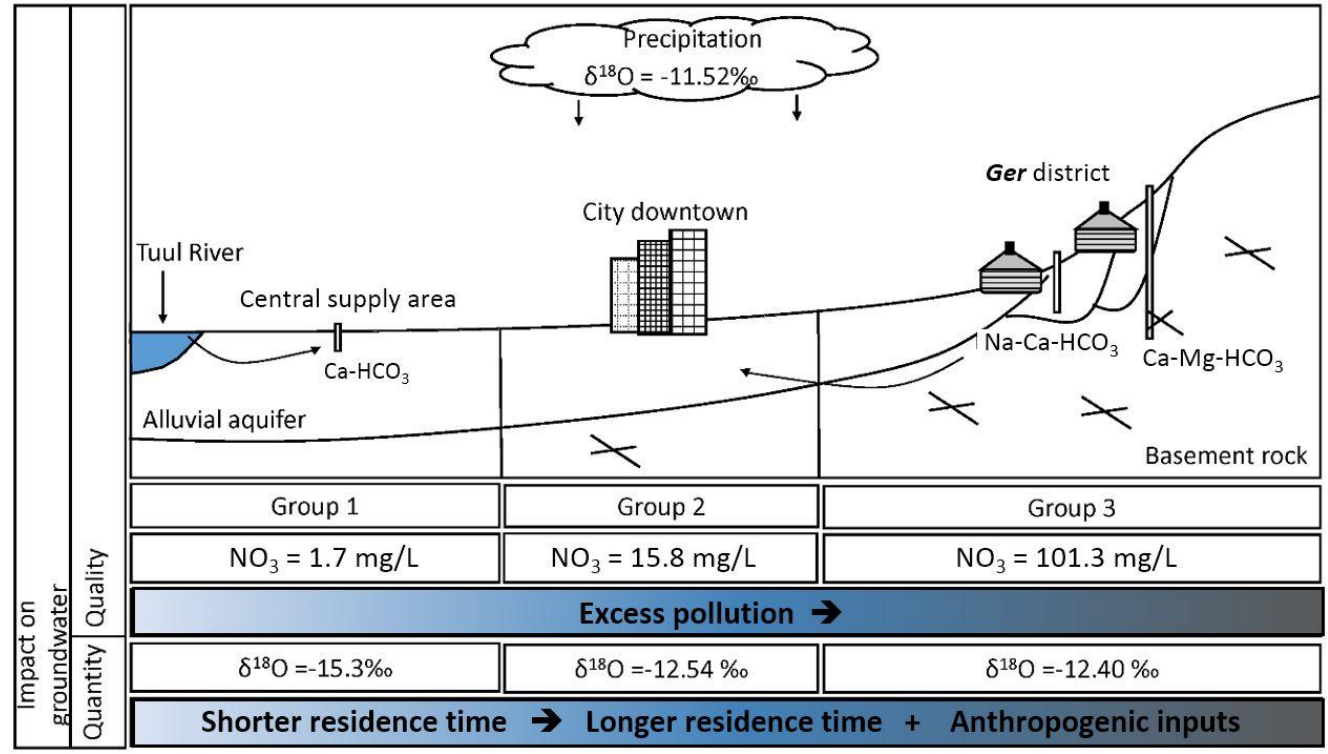

Figure 12. Schematic diagram of the groundwater flow system in Ulaanbaatar.

Author Contributions: N.B. and N.C.W. conceived and designed the research and wrote the paper; N.B. and J.M.L. performed sampling and analysis of the data and proofread a manuscript; and B.N. contributed data collection and discussed about the problems.

Funding: This research was funded by [National Research Foundation of Korea] grant number [NRF-2016K1A3A1A08953551].

Acknowledgments: We extend our deepest appreciation to Enkhbayar Dandar, Batchimeg Gansukh, and Selenge Ganbold for their support and assistance throughout the study. This paper is a part of Naranchimeg Batsaikhan's Ph.D. thesis at Yonsei University.

Conflicts of Interest: The authors declare no conflict of interest.

\section{References}

1. Tsogtbaatar, J.; Janchivdorj, L.; Unurjargal, D.; Erdenechimeg, B. The Groundwater Problem in Mongolia. In UNESCO Chair Workshop on International Strategy for Sustainable Groundwater Management: Transboundary Aquifers and Integrated Watershed Management; UNESCO Office: Beijing, China, 2009; p. 25.

2. Dagvadorj, D.; Natsagadorj, L.; Dorjpurev, J.; Namkhainyam, B. Mongolia Assessment Report on Climate Change; Ministry of Environment, Nature and Tourism of Mongolia: Ulaanbaatar, Mongolia, 2009.

3. Enkhbaatar, D. Strategies for the Sustainable Redevelopment of Residential Buildings in Ulaanbaatar, Mongolia. Master's Thesis, Rmit University, Melbourne, Australia, 2010.

4. National Statistical Office of Mongolia. Bulletin of Statistics, Ulaanbaatar; National Statistical Office of Mongolia: Ulaanbaatar, Mongolia, 2016.

5. Danzan, N. Migration into Ulaanbaatar City; In Workshop on Migration into Cities; Irmgard Coninx Foundation: Berlin, Germany, 2007.

6. Buyankhishig, N.; Aley, M.; Enkhbayar, D. Abstraction Influence on Alluvial Aquifer of the Tuul River, Mongolia. In Trends and Sustainability of Groundwater in Highly Stressed Aquifers; IAHS-AISH Press: Hyderabad, India, 2009; pp. 80-88.

7. Hiller, B.; Jadamba, N. Groundwater use in the Selenge river basin, Mongolia. J. Groundwater Sci. Eng. 2013, 1, 11-32.

8. Jadambaa, N.; Tserenjav, G.; Unurjargal, D. Groundwater in Ulaanbaatar Area. In Ecology and Sustainable Development; The Institute of Geography and Geoecology: Ulaanbaatar, Mongolia, 2000.

9. Battumur, R.; Chuluunbaatar, S. Present Situation and Future Prospective of Drinking and Industrial Water Supply of Ulaanbaatar; Urban Planning Designing Institute of Mongolia: Ulaanbaatar, Mongolia, 2000.

10. Zandaryaa, S.; Borhculuun, U.; Munkhtuya, S. Reserves, consumption and contamination of groundwater in Ulaanbaatar, Mongolia. Atlas Urban Geol. 2003, 14, 445-488. 
11. Kelderman, P.; Batima, P. Water quality assessment of rivers in Mongolia. Water Sci. Technol. 2006, 53, 111-119. [CrossRef] [PubMed]

12. Itoh, M.; Takemon, Y.; Makabe, A.; Yoshimizu, C.; Kohzu, A.; Ohte, N.; Tumurskh, D.; Tayasu, I.; Yoshida, N.; Nagata, T. Evaluation of wastewater nitrogen transformation in a natural wetland (Ulaanbaatar, Mongolia) using dual-isotope analysis of nitrate. Sci. Total Environ. 2011, 409, 1530-1538. [CrossRef] [PubMed]

13. Altansukh, O.; Davaa, G. Application of index analysis to evaluate the water quality of the Tuul River in Mongolia. J. Water Res. Prot. 2011, 3, 398-414. [CrossRef]

14. Dalai, B.; Ishiga, H. Geochemical evaluation of present-day Tuul River sediments, Ulaanbaatar basin, Mongolia. Environ. Monit. Assess. 2013, 185, 2869-2881. [CrossRef] [PubMed]

15. Senjim, B. Changes in River Bed Morphology and Ecology-Tuul River, Mongolia. Geological Issues in Mongolia. Proc. Mong. Acad. Sci. 2005, 5, 112-121.

16. Batkhishig, O. Soil pollution of Ulaanbaatar. Proc. Mong. Acad. Sci. 2016, 53, 15-19.

17. Graham, J.P.; Polizzotto, M.L. Pit latrines and their impacts on groundwater quality: A systematic review. Environ. Health Perspect. 2013, 121, 521-530. [CrossRef] [PubMed]

18. Batjargal, T.; Otgonjargal, E.; Baek, K.; Yang, J.S. Assessment of metals contamination of soils in Ulaanbaatar, Mongolia. J. Hazard. Mater. 2010, 184, 872-876. [CrossRef] [PubMed]

19. Foster, S.S.D; Morris, B.L.; Chilton, P.J. Groundwater in urban development-A review of linkages and concerns. Impacts of Urban Growth on Surface Water and Groundwater Quality. In Proceedings of the IUGG 99, Symposium HS5, Birmingham, UK, 19-30 July 1999.

20. Foster, S.S.D. The interdependence of groundwater and urbanisation in rapidly developing cities. Urban Water J. 2001, 3, 185-192. [CrossRef]

21. Altai, Z.; Stoeckl, N.; King, D. Impacts of water demand side policies on Mongolian residential users. Water Pract. Technol. 2012, 7. [CrossRef]

22. Karthe, D.; Chalov, S.; Borchardt, D. Water resources and their management in central Asia in the early twenty first century: Status, challenges and future prospects. Environ. Earth Sci. 2015, 73, 487-499. [CrossRef]

23. Jadambaa, N. Groundwater Resource Evaluation and Flow System of Artesian Aquifers in Ulaanbaatar Area; Hydrogeology, Moscow University: Moscow, Russia, 1977.

24. Engineering Geological Scientific-Research and Industrial Institute. Exploration for Evaluation Exploitable Groundwater Resource of an Alluvial Aquifer in the Tuul River Basin (Central Part); Engineering Geological Scientific-research and Industrial Institute: Ulaanbaatar, Mongolia, 1979; pp. 1-983.

25. Japan International Cooperation Agency. The Study on Water Supply System in Ulaanbaatar and Surroundings; Japan International Cooperation Agency: Ulaanbaatar, Mongolia, 1995; pp. 1-1056.

26. Buyankhishig, N. Hydrogeological Modeling for the Central Water Supply Source of the Ulaanbaatar City; Hydrogeology, Mongolian University of Science and Technology: Ulaanbaatar, Mongolia, 2008.

27. Fenske, J.; Stephen, E. Development and Application of a Surface-Groundwater flow. Model, of the Tuul River Basin near Ulaanbaatar, Mongolia; US Army Corps of Engineers: Davis, CA, USA, 2016.

28. Dandar, E. Water Resources Assessment in Cold Regions: The Upper Tuul River Basin, Mongolia; Technical University of Catalonia; UPC-Barcelona Tech.: Barcelona, Spain, 2017.

29. Nriagu, J.; Nam, D.; Ayanwola, T.A.; Dinh, H.; Erdenechimeg, E.; Ochir, C.; Bolormaa, T. High levels of uranium in groundwater of Ulaanbaatar, Mongolia. Sci. Total Environ. 2012, 414, 722-726. [CrossRef] [PubMed]

30. Bayartungalag, B. Evaluation of Urban Groundwater Quality at Ulaanbaatar, Mongolia Using Hydrochemical and Environmental Isotope Data; Korea University: Seoul, Korea, 2016.

31. Basandorj, D.; Davaa, G. Tuul River Basin of Mongolia-Integrated Water Resource Management; Interpress: Ulaanbaatar, Mongolia, 2006.

32. Jadambaa, N. Hydrogeology, 8th ed.; Geology and Mineralogy of Mongolia: Ulaanbaatar, Mongolia, 2010.

33. Unudelger, G.; Banzragch, B. Hydrogeological Investigations in Ulaanbaatar Area; Geo-Information Center of Mongolia: Ulaanbaatar, Mongolia, 1993.

34. Buyankhishig, N.; Altantuul, K. Groundwater condition in Ulaanbaatar city, Mongolia. In Proceedings of the 3rd International Forum on Strategic Technologies, Novosibirsk-Tomsk, Russia, 23-29 June 2008; pp. 644-647.

35. IAEA/WISER. Global Networks of Isotopes in Precipitation; IAEA/WISER: Vienna, Austria, 2001.

36. Mora, A.; Mahlknecht, J.; Rosales-Lagarde, L.; Hernández-Antonio, A. Assessment of major ions and trace elements in groundwater supplied to the Monterrey metropolitan area, Nuevo León, Mexico. Environ. Monit. Assess. 2017, 189, 394. [CrossRef] [PubMed] 
37. Nadiri, A.A.; Moghaddam, A.A.; Tsai, F.T.; Fijani, E. Hydrogeochemical analysis for Tasuj plain aquifer, Iran. J. Earth Syst. Sci. 2013, 122, 1091-1105. [CrossRef]

38. Gu, H.; Chi, B.; Li, H.; Jiang, J.; Qin, W.; Wang, H. Assessment of groundwater quality and identification of contaminant sources of Liujiang basin in Qinhuangdao, North China. Environ. Earth Sci. 2015, 73, 6477-6493. [CrossRef]

39. Chae, G.-T.; Yun, S.-T.; Kim, K.; Mayer, B. Hydrogeochemistry of sodium-bicarbonate type bedrock groundwater in the Pocheon spa area, South Korea: Water-rock interaction and hydrologic mixing. J. Hydrol. 2006, 321, 326-343. [CrossRef]

40. Jiang, Y.; Wu, Y.; Groves, C.; Yuan, D.; Kambesis, P. Natural and anthropogenic factors affecting the groundwater quality in the Nandong karst underground river system in Yunan, China. J. Contam. Hydrol. 2009, 109, $49-61$. [CrossRef] [PubMed]

41. Gibbs, R.J. Mechanisms controlling world water chemistry. Science 1970, 170, 1088-1090. [CrossRef] [PubMed]

42. Hounslow, W. Water Quality Data: Analysis and Interpretation; CRC Press: Boca Raton, FL, USA, 1995.

43. Appelo, C.A.J.; Postma, D. Geochemistry, Groundwater and Pollution; CRC Press: Boca Raton, FL, USA, 2004.

44. Craig, H. Isotopic variations in meteoric waters. Science 1961, 133, 1702-1703. [CrossRef] [PubMed]

45. Tsujimura, M.; Abe, Y.; Tanaka, T.; Shimada, J.; Higuchi, S.; Yamanaka, T.; Davaa, G.; Oyunbaatar, D. Stable isotopic and geochemical characteristics of groundwater in Kherlen river basin, a semi-arid region in Eastern Mongolia. J. Hydrol. 2007, 333, 47-57. [CrossRef]

46. Zhang, B.; Song, X.; Zhang, Y.; Han, D.; Tang, C.; Yu, Y.; Ma, Y. Hydrochemical characteristics and water quality assessment of surface water and groundwater in Songnen plain, Northeast China. Water Res. 2012, 46, 2737-2748. [CrossRef] [PubMed]

47. Harvey, F.E.; Welker, J.M. Stable isotopic composition of precipitation in the semi-arid north-central portion of the US Great Plains. J. Hydrol. 2000, 238, 90-109. [CrossRef]

48. Dogramaci, S.; Skrzypek, G.; Dodson, W.; Grierson, P.F. Stable isotope and hydrochemical evolution of groundwater in the semi-arid Hamersley basin of subtropical Northwest Australia. J. Hydrol. 2012, 475, 281-293. [CrossRef]

49. Clark, I.D.; Fritz, P. Environmental Isotopes in Hydrogeology; CRC Press: Boca Raton, FL, USA, 1997.

50. Jouzel, J.; Froehlich, K.; Schotterer, U. Deuterium and oxygen-18 in present-day precipitation: Data and modelling. Hydrol. Sci. J. 1997, 42, 747-763. [CrossRef]

51. Kendall, C.; Doctor, D. Stable isotope applications in hydrologic studies. Treatise Geochem. 2003, 5, 319-364.

52. Terwey, J.L. Isotopes in groundwater hydrology. In Challenges in African Hydrology and Water Resources (Proceedings of the Harare Symposium); International Association of Hydrological Sciences: Wallingford, UK, 1984.

53. Gomo, M.; van Tonder, G.J.; Steyl, G. Investigation of the hydrogeochemical processes in an alluvial channel aquifer located in a typical Karoo basin of Southern Africa. Environ. Earth Sci. 2013, 70, 227-238. [CrossRef]

54. Spaliding, R.; Exner, M. Occurrence of nitrate in groundwater. A review: J. Environ. Qual. 1993, 22, $392-402$.

55. World Health Organization. Guidelines for Drinking-Water Quality; First Addendum to the Fourth Edition; World Health Organization: Geneva, Switzerland, 2017; p. 541.

56. Ward, M.H.; Mark, S.D.; Cantor, K.P.; Weisenburger, D.D.; Correa-Villasenor, A.; Zahm, S.H. Drinking water nitrate and the risk of Non-Hodgkin's lymphoma. Epidemiology 1996, 7, 465-471. [CrossRef] [PubMed]

57. Weyer, P.J.; Cerhan, J.R.; Kross, B.C.; Hallberg, G.R.; Kantamneni, J.; Breuer, G.; Jones, M.P.; Zheng, W.; Lynch, C.F. Municipal drinking water nitrate level and cancer risk in older women: The Iowa women's health study. Epidemiology 2001, 12, 327-338. [CrossRef] [PubMed]

58. Stallard, R.; Edmond, J. Geochemistry of the amazon: 2. The influence of geology and weathering environment on the dissolved load. J. Geophys. Res.-Oceans 1983, 88, 9671-9688. [CrossRef]

(C) 2018 by the authors. Licensee MDPI, Basel, Switzerland. This article is an open access article distributed under the terms and conditions of the Creative Commons Attribution (CC BY) license (http:// creativecommons.org/licenses/by/4.0/). 